\title{
Hypopharyngeal Cancer cM0 TNM Finding v8
}

National Cancer Institute

\section{Source}

National Cancer Institute. Hypopharyngeal Cancer cMO TNM Finding v8. NCI Thesaurus.

Code C132985.

Hypopharyngeal cancer without evidence of distant metastasis. (from AJCC 8th Ed.) 